\title{
Fiber characteristics in tropical aquatic plants for handmade papermaking
}

\begin{abstract}
This study was performed to explore aquatic plants potential as raw materials to be used as alternative fibers in papermaking. Aquatic plants; Eleocharis dulcis, Limnocharis flava, Nymphaea nouchali, Blyxa aubertii and Cyperus malaccensis were collected from wetland areas and used as raw materials for handmade papermaking. Variables include; cell wall thickness, fiber diameter, lumen diameter and fiber length were examined and measured. Nymphaea nouchali possessed comparatively longer fiber length $(0.571 \mathrm{~mm})$, wider fiber diameter $(48.17 \mu \mathrm{m})$ and lumen diameter $(38.46 \mu \mathrm{m})$. Cyperus malaccensis has shorter fiber length $(0.093 \mathrm{~mm})$ and B. aubertii has narrower fiber diameter $(16.1 \mu \mathrm{m})$ and cell wall thickness $(3.77 \mu \mathrm{m})$. With respect to slenderness ratio (index to determine the strength of paper), B. aubertii possessed higher slenderness ratio of 16.4. All the species examined in this study have less than one Runkel ratio except for L. flava. Flexibility coefficient for the species evaluated ranged between 40.90-80.06\%. Cyperus malaccensis, B. aubertii and N. nouchali have flexibility coefficient within standard range for papermaking suitability which were $53.8 \%, 61.78 \%$ and $80.06 \%$, respectively. The slenderness ratio, Runkel ratio and flexibility coefficient characteristics contribute to tissue stability and have effect on the properties of handmade paper. Fiber distribution in produced paper sheets varied from random to uniform distribution. Limnocharis flava have higher shrinkage rate $(11.43 \%)$ compared to other species whereas $\mathrm{C}$. malaccensis possessed lowest shrinkage rate $(3.93 \%)$.
\end{abstract}

Keyword: Papermaking; Aquatic plants; Fiber dimensions; Fiber distributions; Paper shrinkage; Handmade paper 